\title{
Effects of physical therapy interventions on balance ability in people with traumatic brain injury: A systematic review
}

\author{
Anas R. Alashram ${ }^{\mathrm{a}, \mathrm{b}, *}$, Giuseppe Annino ${ }^{\mathrm{b}}$, Manikandan Raju ${ }^{\mathrm{c}}$ and Elvira Padua ${ }^{\mathrm{d}}$ \\ a PhD School of Neuroscience, Faculty of Medicine and Surgery, University of Rome "Tor Vergata", Italy \\ ${ }^{\mathrm{b}}$ Department of Medicine Systems, University of Rome "Tor Vergata”, Italy \\ ${ }^{\mathrm{c} S c h o o l}$ of Clinical/Experimental Neuroscience and Psychology, Department of Neuroscience Umane, \\ University of Sapienza, Rome, Italy \\ ${ }^{\mathrm{d}}$ Department of Human Sciences and Promotion of the Quality of Life, San Raffaele Roma Open University, \\ Rome, Italy
}

\begin{abstract}
.
BACKGROUND: Balance deficits are common impairments in individuals with post-traumatic brain injury (TBI). Balance deficits can restrict the activities of daily living and productive participation in social life. To date, no systematic reviews have examined the impact of physical therapy intervention on balance post-TBI.

OBJECTIVE: To examine the effects of physical therapy interventions on balance impairments in individuals with TBI. METHODS: We systematically searched in PubMed, EMBASE, Scopus, PEDro, MEDLINE, REHABDATA, and Web of Science for randomized controlled trials (RCTs), clinical control trials, and pilot studies that examined the effects of physical therapy interventions on balance deficits in individuals post-TBI. The methodological quality was estimated using the Physiotherapy Evidence Database (PEDro) scale.

RESULTS: Eight studies published from 2003 to 2019 were included in this study. A total of 259 TBI participants post-TBI were included in this review, 71 (27.41\%) of which were females. The methodological quality of the selected studies ranged from low to high. There were no significant differences between experimental interventions, virtual reality (VR), vestibular rehabilitation therapy (VRT), control group interventions, and other traditional physical therapy interventions.

CONCLUSIONS: The evidence about the effects of the physical therapy interventions in improving the balance ability post-TBI was limited. Further randomized controlled trials are strongly warranted to understand the role of physical therapy in patients with TBI who complain about balance deficits.
\end{abstract}

Keywords: Brain injuries, trauma, postural balance, rehabilitation, therapeutics, systematic review, neurological rehabilitation

\footnotetext{
*Address for correspondence: Anas R. Alashram, Neuroscience PhD school, Department of Medicine systems, Faculty of Medicine and Surgery, University of Rome "Tor Vergata", Montpellier Street, 00133, Rome, Italy. E-mail: anasalashram@gmail. com; ORCID ID: 0000-0002-3066-3943
}

\section{Introduction}

Balance deficits and postural instability are very prevalent in people with traumatic brain injury (TBI) (Walker \& Pickett, 2007). It affects 39-62\% of individuals following TBI (Marsh et al., 2016). Declined 
balance abilities are linked with longer inpatient lengths of stay (Greenwald et al., 2001; Black et al., 2000), developed the risk of falling (Feld et al., 2001), delayed recoveries, increased medical complications (Greenwald et al., 2001), and gait abnormalities (Wade et al., 1997). Balance deficits can restrict the activities of daily living (ADLs) and participation in social activities (Marsh et al., 2016; Hsieh et al., 2002). Despite enhancements in balance that occur from 0 to 6 months post-TBI, balance impairments remain one of the most frequently observed chronic impairments for individuals with TBI (Walker \& Pickett, 2007).

Balance is defined as the ability to sustain the gravity line within the base of support (BOS) with minimal postural sway (Shumway-Cook et al., 1988). Balance control is a whole process relying on the combination of visual, vestibular, and somatosensory inputs to the central nervous system (CNS) (Shaffer \& Harrison, 2007). Balance deficits resulting from failures in the complex connections between the sensory, motor, and musculoskeletal systems are very common in individuals with TBI (1). Generally, many factors contribute to impaired balance ability: (1) biomechanics and joint kinematics, (2) sensorimotor and neural control, (3) dysregulation of cardiopulmonary, and (4) cognition, psychology and fear of falling (Peterson \& Greenwald, 2015).

Generally, numerous rehabilitation therapies have been used in balance rehabilitation in patients with various neurological disorders such as; rhythmic auditory stimulation (RAS) (Alashram et al., 2019a), whole-body vibration (WBV) (Alashram et al., 2019b), Virtual reality (VR) (Alashram et al., 2020), exercise (Schmid et al., 2012), mirror therapy (MT) (Broderick et al., 2018), traditional atient medicine (TCM) (Xu et al., 2018), and traditional Chinese exercise (TCE) (Chen et al., 2015). Focusing on balance rehabilitation post-TBI, the balance enhanced following traditional physical therapy based on motor learning principles particularly tailored for treating postural and coordination deficits (Ustinova et al., 2015). A literature review by Pietrzak et al. (2014) investigated the effect of VR on the cognitive and motor symptoms in individuals with TBI, and it is not limited to the balance. Furthermore, the systematic reviews by Murray et al. (2016) and Booth et al. (2019) investigated the influence of the vestibular rehabilitation therapy (VRT) post-TBI. However, they were limited to the vestibular rehabilitation interventions and to individuals with a concussion. To date, no systematic reviews have been established to clarify the role of physical therapy in balance rehabilitation post-TBI. Therefore, the current review aimed to investigate the influence of physical therapy interventions on balance ability in individuals with TBI.

\section{Methods}

\subsection{Search strategy}

A systematic search was carried out in PubMed, Scopus, PEDro, EMBASE, MEDLINE, REHABDATA, and Web of Science. The search terms were (rehabilitation OR balance rehabilitation OR physical activity OR exercise OR modalities OR therapy OR physical therapy OR occupational therapy OR training) AND (traumatic brain injury OR trauma OR concussion OR TBI) AND (balance OR balance ability OR fall OR postural control OR postural OR function). No time restriction was applied to the search that was completed in December 2019 (Fig. 1).

\subsection{Study selection}

The inclusion criteria were built according to the PICOS approach (P: participants; I: interven-

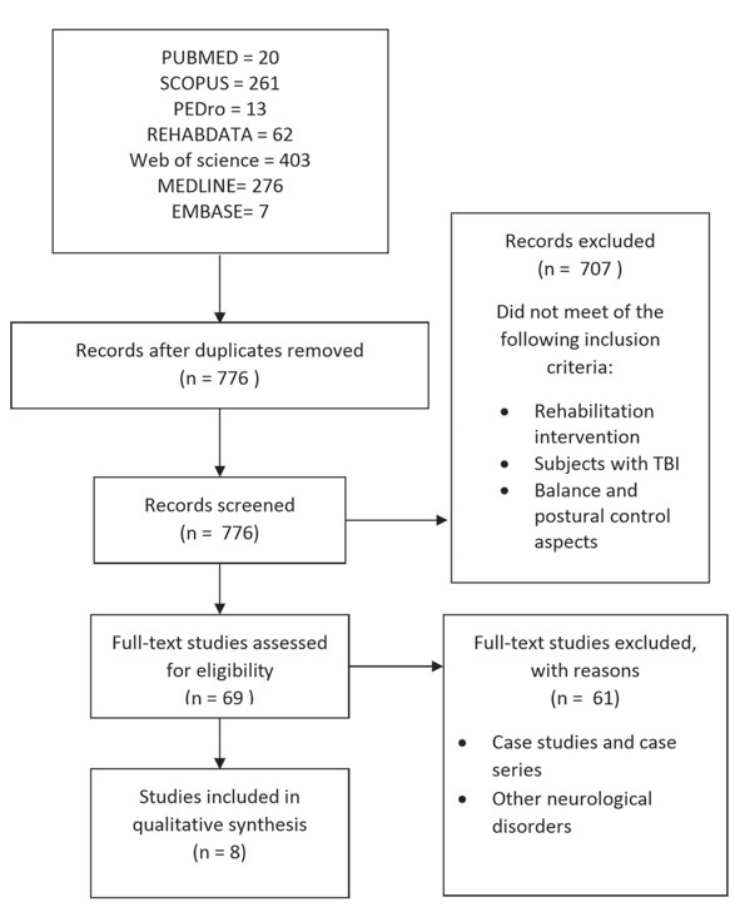

Fig. 1. Summary of the literature review process. 
tion; C: comparison; O: outcomes; S: study design). The inclusion criteria details are clarified as follows: (1) P: adults with traumatic brain injury; (2) I: the experimental received balance rehabilitation interventions; (3) $\mathrm{C}$ : conventional physical therapy interventions, no-intervention control, same experimental on healthy subjects or no control; (4) O: the outcomes were the balance ability assessments; and (5) S: randomized controlled trial, clinical control trials, and pilot studies. The exclusion criteria were: (1) animal models; (2) pharmacological intervention as the main intervention; (3) descriptive, case studies or case series study design; and (4) subjects with no confirmed diagnosis for traumatic brain injury.

Two independent authors independently screened the titles and abstracts of the studies first to identify their possible relevance. The authors then additionally decided on the eligibility of the included studies by reviewing the full text. Any disagreements were resolved by discussing the study with a third author.

\subsection{Data extraction and analysis}

After reviewing the results of the selected studies, the meta-analysis was not proper because of different outcomes and the large heterogeneity of the selected studies. The data were independently extracted by two authors and then checked by the third author. The data were extracted separately: (1) study design and participants, (2) treatment sessions details, (3) experimental intervention, and (4) control group intervention (Table 2). Table 3 displays outcome measures, effect sizes were calculated by dividing the difference between the means of groups by the pooled SD (Ialongo, 2016). The effect size (ES) was identified using Cohen's d: more than 0.8 was large, 0.5 moderate, and less than 0.2 small (Cohen, 1988). The current review follows all PRISMA guidelines and reports the essential information accordingly.

\subsection{Methodological quality}

Two reviewers independently evaluated the methodological quality of the selected studies using the PEDro scale. The scale comprises eleven items addressing external validity, internal validity, and interpretability. The PEDro is scaleable to identify potential bias with fair to good reliability (Maher et al., 2003) and is a valid measure of the methodological quality of scientific trials. With the difference of results among paired groups of selected studies, the result of the studies with a higher PEDro score was given more attention ( $>6$ High quality). Any disagreements were resolved by discussion between both reviewers. Methodological quality scores for selected studies are presented in Table 1. The selected studies in the current systematic review were level I and II classified for the level of evidence provided by Sackett's, (1989).

\section{Results}

\subsection{Study selection}

A systematic search of PubMed (yielding 20 studies), Scopus (261), PEDro (13), REHABDATA (62), MEDLINE (276), EMBASE (7), and Web of Science (403) formed a total of 1042 studies. After eliminating duplicates, 776 studies were reviewed. Out of those, 707 studies were excluded because their abstracts displayed that they did not met the inclusion criteria. Sixty-nine studies were exposed to more detailed analysis because their abstracts did not expose that they fulfilled the inclusion criteria. Sixtyone studies were removed for the following causes; case studies/case series and other neurological disorders. A total of eight studies were recognized for the inclusion criteria in the current review. The process of studies selected for the current systematic review is displayed in Fig. 1

\subsection{Description of selected studies}

\subsubsection{Participants}

The PICOS approach (Patients, Intervention, Control, Outcomes, and Study design) was followed (Liberati et al., 2009). Eight studies met the inclusion criteria (Peters et al., 2014; Damiano et al., 2016; Kleffelgaard et al., 2018; Cuthbert et al., 2014; Straudi et al., 2017; Cuff et al., 2014; Sveistrup et al., 2003; Thornton et al., 2005). A total of 259 patients post-TBI were included in this review, $71(27.41 \%)$ of which were females. Except for Cuff et al., 2014, the selected studies included TBI patients who $\geq 18$ years of age. In terms of injury duration, three studies included chronic TBI patients ( $\geq 6$ months postTBI) (Damiano et al., 2016; Straudi et al., 2017; Sveistrup et al., 2003), two included acute and subacute TBI patients ( $<6$ months post-TBI) (Cuthbert et al., 2014; Thornton et al., 2005), one included subacute and chronic ( $\geq 3$ months post-TBI) (Peters et al., 2014), and one included acute, subacute and chronic TBI (3.5 \pm 2.1 months post-TBI) (Kleffelgaard et al., 
Table 1

Methodological quality scores

\begin{tabular}{|c|c|c|c|c|c|c|c|c|c|c|c|}
\hline $\begin{array}{l}\text { Author, } \\
\text { Year }\end{array}$ & $\begin{array}{l}\text { Random } \\
\text { allocatio }\end{array}$ & $\begin{array}{l}\text { n Concealed } \\
\text { on allocation }\end{array}$ & $\begin{array}{l}\text { Groups } \\
\text { similar at } \\
\text { baseline }\end{array}$ & $\begin{array}{l}\text { Participant } \\
\text { t blinding }\end{array}$ & $\begin{array}{l}\text { Therapist } \\
\text { blinding }\end{array}$ & $\begin{array}{l}\text { Assessor } \\
\text { blinding }\end{array}$ & $\begin{array}{c}<15 \% \\
\text { dropouts }\end{array}$ & $\begin{array}{l}\text { Intention } \\
\text { to treat } \\
\text { analysis }\end{array}$ & $\begin{array}{l}\text { Between- } \\
\text { group } \\
\text { differences } \\
\text { reported }\end{array}$ & $\begin{array}{c}\text { Point } \\
\text { estimate and } \\
\text { s variability } \\
\text { reported }\end{array}$ & $\begin{array}{c}\text { Total } \\
(0 \text { to } 10)\end{array}$ \\
\hline Peters et al., 2014 & $\mathrm{~N}$ & $\mathrm{~N}$ & $\mathrm{~N}$ & $\mathrm{~N}$ & $\mathrm{~N}$ & $\mathrm{~N}$ & $\mathrm{Y}$ & $\mathrm{Y}$ & $\mathrm{N}$ & $\mathrm{Y}$ & 3 \\
\hline Damiano et al., 2016 & $\mathrm{~N}$ & $\mathrm{~N}$ & $\mathrm{Y}$ & $\mathrm{N}$ & $\mathrm{N}$ & $\mathrm{N}$ & $\mathrm{Y}$ & $\mathrm{N}$ & $\mathrm{N}$ & $\mathrm{Y}$ & 4 \\
\hline Kleffelgaard et al., 2019 & Y & $\mathrm{Y}$ & Y & $\mathrm{N}$ & $\mathrm{N}$ & Y & Y & $\mathrm{Y}$ & Y & $\mathrm{Y}$ & 8 \\
\hline Cuthbert et al., 2014 & $\mathrm{Y}$ & $\mathrm{N}$ & $\mathrm{Y}$ & $\mathrm{N}$ & $\mathrm{N}$ & $\mathrm{Y}$ & $\mathrm{Y}$ & $\mathrm{Y}$ & $\mathrm{Y}$ & $\mathrm{Y}$ & 7 \\
\hline Straudi et al., 2017 & $\mathrm{Y}$ & $\mathrm{N}$ & $\mathrm{Y}$ & $\mathrm{N}$ & $\mathrm{N}$ & $\mathrm{Y}$ & $\mathrm{Y}$ & $\mathrm{Y}$ & $\mathrm{Y}$ & $\mathrm{Y}$ & 7 \\
\hline Cuff et al., 2014 & $\mathrm{Y}$ & $\mathrm{N}$ & $\mathrm{Y}$ & $\mathrm{N}$ & $\mathrm{N}$ & $\mathrm{Y}$ & $\mathrm{Y}$ & $\mathrm{Y}$ & $\mathrm{Y}$ & $\mathrm{N}$ & 6 \\
\hline Sveistrup et al., 2003 & $\mathrm{Y}$ & $\mathrm{N}$ & $\mathrm{Y}$ & $\mathrm{N}$ & $\mathrm{N}$ & $\mathrm{N}$ & $\mathrm{Y}$ & $\mathrm{Y}$ & $\mathrm{N}$ & $\mathrm{Y}$ & 5 \\
\hline $\begin{array}{l}\text { Thornton et al., } 2005 \\
\text { Median: } 6\end{array}$ & $\mathrm{Y}$ & $\mathrm{N}$ & $\mathrm{Y}$ & $\mathrm{N}$ & $\mathrm{N}$ & $\mathrm{N}$ & $\mathrm{Y}$ & $\mathrm{Y}$ & $\mathrm{N}$ & $\mathrm{Y}$ & 5 \\
\hline
\end{tabular}

2018). Table 2 displays the selected studies' characteristics.

\subsubsection{Intervention}

Three randomized controlled trials used VR training to improve balance ability in patients with TBI (Cuthbert et al., 2014; Sveistrup et al., 2003; Thornton et al., 2005). In the study by Cuthbert et al. (2014), the participants in the experimental group participated 15 minutes of balance exercises using the Wii Fit and Wii games plus conventional physiotherapy intervention at the end of the session. The VR training intervention consisted of eight minutes of Wii Fit balance board games and seven minutes of Wii sports games four times per week for four weeks. During days one and three of each week, patients completed eight minutes of Table-Tilt plus seven minutes of Tennis, while on days two and four they completed eight minutes of Penguin Slide plus seven minutes of Bowling. The control group received Extra Standard Balance Care (ESC). Moreover, Sveistrup et al. (2003) used numerous situations are used that need subjects to work on reaching, moving within the BOS, stepping, sit-tostand, hopping, jumping and jogging for 60 minutes, three times a week for six weeks. The control group did not receive any intervention. Furthermore, the VR treatment approach used in the study by Thornton et al. (2005) is a modified IREX* computerized program. The Patients asked to make large body movements to interrelate with virtual objects in a virtual environment. The treatment sessions duration was 50 minutes, three times per week for six weeks. The control group received traditional activity balance training.

Concerning vestibular rehabilitation therapy, two randomized controlled trials were included $(29,32)$. In the study by Kleffelgaard et al. (2019), the participants in the experimental group received usual multidisciplinary outpatient rehabilitation in addition to a vestibular rehabilitation for 60 minutes, two times per week for eight weeks. The intervention consisted of supervision, tailored exercises, a home-based exercise, and an exercise diary. The individual adapting of exercises was depend on symptoms and challenges at each participant's baseline evaluations. The exercises included Brandt-Daroff exercises for benign paroxysmal positional vertigo (BPPV), habituation exercises for motion sensitivity and vertigo, gaze-stabilization exercises for symptoms showed during eye-head coordination and decreased vestibule-ocular reflex (VOR), and exercises for limited balance centering on improving sensory integration. The home-based exercise consisted of 2-5 modified exercises and physical activity. The exercise diary was utilized to enhance awareness and motivation, as well to record the achieved exercises and the patients' responses to them. The control group usual multidisciplinary outpatient rehabilitation only. A study by Cuff et al. (2014), the abstract only was included because there is no full text available. The participants in the experimental group received vestibular rehabilitation therapy seven times a week for two weeks. The control group did not receive any intervention.

The study by Straudi et al. (2017) used video game therapy (VGT) (X-Box 360 Kinect, Microsoft, Inc., Redmond, WA). Pre-selected games included a varied range of activities in an upright position. Particularly, postural balance and mobility-related motor tasks and arm goal-reaching were exercised. The VGT provided various feedback: visual and augmented. Participants trained for 2-5 min during each game, three times a week for six weeks. The control group received balance platform therapy. On the other hand, the elliptical trainer device was used in the study by Damiano et al. (2016). The participants 
Table 2

Characteristics of the selected studies

\begin{tabular}{|c|c|c|c|c|}
\hline Author, Year & $\begin{array}{l}\text { Study design \& } \\
\text { Participants }\end{array}$ & $\begin{array}{l}\text { Treatment session } \\
\text { details }\end{array}$ & Experimental intervention & Control intervention \\
\hline \multirow[t]{6}{*}{$\begin{array}{l}\text { Peters et al., } \\
2014\end{array}$} & Study design: Pilot & $\begin{array}{l}20 \text { sessions of } 150 \\
\text { minutes, }(5 \text { sessions } \\
\text { per wk } \times 4 \text { weeks }) .\end{array}$ & $\begin{array}{l}\text { 1) gait training BWST (50 } \\
\text { min) }\end{array}$ & NA \\
\hline & Level: II & & 2) balance exercises (50 $\mathrm{min})$ & \\
\hline & Sample: 10 & & $\begin{array}{l}\text { 3) strength, coordination, and } \\
\text { ROM (50 min) }\end{array}$ & \\
\hline & $\operatorname{Sex}(M / F): 8 / 2$ & & & \\
\hline & $\begin{array}{l}\text { Age (Mean): } \geq 18 \text { years } \\
\text { of age }\end{array}$ & & & \\
\hline & $\begin{array}{l}\text { Duration of Injury: }(\geq 6 \\
\text { months post-TBI) }\end{array}$ & & & \\
\hline \multirow[t]{6}{*}{$\begin{array}{l}\text { Damiano } \\
\text { et al., } 2016\end{array}$} & $\begin{array}{l}\text { Study design: Clinical } \\
\text { trial }\end{array}$ & $\begin{array}{l}40 \text { sessions of } 30 \\
\text { minutes, }(5 \text { sessions } \\
\text { per wk for } 8 \text { weeks })\end{array}$ & (TBI participants) & (Healthy participants) \\
\hline & Level: II & & Elliptical trainer device & Elliptical trainer device \\
\hline & Sample: 24 (12 TBI) & & $\begin{array}{l}\text { (40-80 RPM or a cadence of } \\
80-160 \text { steps per min) } \\
\text { Gradually increase } \\
\text { throughout the training } \\
\text { program. }\end{array}$ & $\begin{array}{l}\text { Same experimental training } \\
\text { protocol }\end{array}$ \\
\hline & $\operatorname{Sex}(M / F): 7 / 5$ & & & \\
\hline & Age (Mean): $31.3 \pm 9.4$ & & & \\
\hline & $\begin{array}{l}\text { Duration of Injury: ( } \geq 6 \\
\text { months post-TBI) }\end{array}$ & & & \\
\hline \multirow[t]{6}{*}{$\begin{array}{l}\text { Kleffelgaard } \\
\text { et al., } 2019\end{array}$} & Study design: RCT & $\begin{array}{l}16 \text { sessions of } 60 \\
\text { minutes }(2 \text { sessions } \\
\text { per wk for } 8 \mathrm{wks})\end{array}$ & Usual multidisciplinary & Usual multidisciplinary \\
\hline & Sample: 65 & & $\begin{array}{l}\text { outpatient } \\
\text { rehabilitation+group-based } \\
\text { vestibular rehabilitation } \\
\text { intervention (tailored } \\
\text { exercises, a HEP, and an } \\
\text { exercise diary). }\end{array}$ & outpatient rehabilitation \\
\hline & Level: I & & & \\
\hline & $\operatorname{Sex}(M / F): 20 / 45$ & & & \\
\hline & Age (Mean): 39.34 & & & \\
\hline & $\begin{array}{l}\text { Duration of Injury: Acute } \\
\text { and Chronic ( } 3.5 \pm 2.1 \\
\text { months after injury) }\end{array}$ & & & \\
\hline \multirow[t]{6}{*}{$\begin{array}{l}\text { Cuthbert et al., } \\
2014\end{array}$} & Study design: RCT & $\begin{array}{l}16 \text { sessions of } 15 \\
\text { minutes (4 sessions } \\
\text { per wk for } 4 \text { wks) }\end{array}$ & $\begin{array}{l}\text { Balance exercises using the } \\
\text { Wii Fit and Wii Sport } \\
\text { interactive } \\
\text { games+traditional } \\
\text { physiotherapy regimen at } \\
\text { the end of the training day. }\end{array}$ & $\begin{array}{l}\text { Extra Standard Balance Care } \\
\text { (ESC): }\end{array}$ \\
\hline & Level: I & & & $\begin{array}{l}\text { Balance-specific } \\
\text { training+traditional } \\
\text { physiotherapy regimen at the } \\
\text { end of the training day. }\end{array}$ \\
\hline & Sample: 20 & & & \\
\hline & $\operatorname{Sex}(M / F): 13 / 7$ & & & \\
\hline & $\begin{array}{l}\text { Age (Mean): } \geq 18 \text { years } \\
\text { of age }\end{array}$ & & $\begin{array}{l}\text { The training session consisted } \\
\text { of } 8 \text { mins of Wii Fit balance } \\
\text { board games and } 7 \text { mins of } \\
\text { Wii sport games }\end{array}$ & \\
\hline & $\begin{array}{l}\text { Duration of Injury: }(<6 \\
\text { months post-TBI) }\end{array}$ & & & \\
\hline
\end{tabular}


Table 2

(continued)

\begin{tabular}{|c|c|c|c|c|}
\hline Author, Year & $\begin{array}{c}\text { Study design \& } \\
\text { Participants }\end{array}$ & $\begin{array}{l}\text { Treatment session } \\
\text { details }\end{array}$ & Experimental intervention & Control intervention \\
\hline \multirow[t]{6}{*}{$\begin{array}{l}\text { Straudi et al., } \\
2017\end{array}$} & Study design: RCT & $\begin{array}{l}18 \text { sessions ( } 3 \\
\text { sessions per wk for } \\
6 \text { wks). }\end{array}$ & Video game therapy & Balance platform therapy \\
\hline & Level: I & & $\begin{array}{l}\text { Provided various feedback: } \\
\text { visual and augmented } \\
\text { feedback (knowledge of } \\
\text { both results and } \\
\text { performance) using video } \\
\text { game console (X-Box } 360 \\
\text { Kinect, Microsoft, Inc., } \\
\text { Redmond, WA). }\end{array}$ & $\begin{array}{l}\text { Balance, postural stability and } \\
\text { weight-shifting training with } \\
\text { and without visual feedback } \\
\text { using a balance platform } \\
\text { (Biodex Medical Systems, Inc., } \\
\text { Shirley, NY) }\end{array}$ \\
\hline & Sample: 21 & & & \\
\hline & $\operatorname{Sex}(M / F): 17 / 4$ & & & \\
\hline & Age (Mean): 36 & & & \\
\hline & $\begin{array}{l}\text { Duration of Injury: }(\geq 6 \\
\text { months post-TBI) }\end{array}$ & & $\begin{array}{l}\text { Patients trained for } 2-5 \mathrm{~min} \\
\text { during each game. }\end{array}$ & \\
\hline \multirow[t]{6}{*}{$\begin{array}{l}\text { Cuff et al., } \\
2014\end{array}$} & Study design: RCT & $\begin{array}{l}14 \text { sessions }(7 \\
\text { sessions per wk for } \\
2 \text { wks) }\end{array}$ & VRT exercise & Rest \\
\hline & Level: I & & & \\
\hline & Sample: 62 & & & \\
\hline & $\operatorname{Sex}(M / F): N R$ & & & \\
\hline & $\begin{array}{l}\text { Age (Mean): }(<18 \text { years } \\
\text { of age) }\end{array}$ & & & \\
\hline & Duration of Injury: NR & & & \\
\hline \multirow[t]{6}{*}{$\begin{array}{l}\text { Sveistrup } \\
\text { et al., } 2003\end{array}$} & Study design: RCT & $\begin{array}{l}18 \text { sessions of } 60 \\
\text { minutes ( } 3 \text { sessions } \\
\text { per wk for } 6 \text { wks) }\end{array}$ & $\begin{array}{l}\text { System: Commercial, IREX } \\
\text { (developed by GestureTek }\end{array}$ & No exercise \\
\hline & Level: II & & Health Canada) & \\
\hline & Sample: 42 & & $\begin{array}{l}\text { Intervention 1: Eighteen } \\
\text { 1-hour sessions of balance } \\
\text { training, } 3 \text { times/week. }\end{array}$ & \\
\hline & $\operatorname{Sex}(M / F): N R$ & & $\begin{array}{l}\text { Multiple VR scenarios } \\
\text { required reaching, moving } \\
\text { within the BOS, stepping, } \\
\text { sit-to-stand, hopping, } \\
\text { jumping, and jogging. }\end{array}$ & \\
\hline & Age (Mean): NR & & & \\
\hline & $\begin{array}{l}\text { Duration of Injury: }(\geq 6 \\
\text { months post-TBI) }\end{array}$ & & $\begin{array}{l}\text { Intervention 2: As above but } \\
\text { performed as conventional } \\
\text { exercise }\end{array}$ & \\
\hline \multirow[t]{6}{*}{$\begin{array}{l}\text { Thornton } \\
\text { et al., } 2005\end{array}$} & Study design: RCT & $\begin{array}{l}18 \text { sessions of } 50 \\
\text { minutes ( } 3 \text { sessions } \\
\text { per wk for } 6 \text { wks })\end{array}$ & $\begin{array}{l}\text { System: Commercial, } \\
\text { modified IREX. It required } \\
\text { patients to make large body } \\
\text { movements to interact with } \\
\text { virtual objects. }\end{array}$ & $\begin{array}{l}\text { Traditional activity balance } \\
\text { training that incorporated } \\
\text { walking, running, and exercises } \\
\text { with balls and stools }\end{array}$ \\
\hline & Level: II & & & \\
\hline & Sample: 27 & & & \\
\hline & $\operatorname{Sex}(M / F): 19 / 8$ & & & \\
\hline & Age (Mean): 39.78 & & & \\
\hline & $\begin{array}{l}\text { Duration of Injury: }(<6 \\
\text { months post-TBI) }\end{array}$ & & & \\
\hline
\end{tabular}

RPM: revolutions per minute; HEP: home exercise programme; VRT: vestibular rehabilitation therapy; PT: physiotherapy; ESC: Extra Standard Balance Care; IRF: inpatient rehabilitation facility; VR: virtual reality; NR: not reported, NA: not applicable; BWST: body weight support treadmill; ROM: range of motion; BOS: base of body support; *Expressed as a median.

asked to achieve and keep a rapid pace (40-80 RPM or 80-160 steps/min) gradually increase throughout the program. Minor resistance to leg motion was applied firstly and progressively increased. All patients were instructed to exercise five days a week for $30 \mathrm{~min}$, for eight weeks. The control group included healthy par- 
ticipants who received the same experimental group intervention.

Lastly, in the pilot study by Peters et al. (2014), the participants underwent 20 treatment sessions (5 sessions per week for 4 weeks). During each training session, patients were requested to achieve 50 minutes in three various activities domains (total 150 minutes/session): 1) gait training with a body weight support (BWS) treadmill, 2) balance exercises, and 3) strength, coordination, and range of motion (ROM).

\subsection{Outcome measures}

The selected studies used various scales to assess balance ability in patients with TBI. The scales that were used: Berg Balance Scale (BBS) (Peters et al., 2014; Cuthbert et al., 2014), Dynamic Gait Analysis (DGI) (Peters et al., 2014), Limits of StabilityReaction Time Backwards LOS (RT-B) (Damiano et al., 2016), Motor Control Test (MCT) (Damiano et al., 2016), Balance Error Scoring System (BBES) (Kleffelgaard et al., 2018), Unified Balance Scale (UBS) (Straudi et al., 2017), force platform (Straudi et al., 2017), Self-reported balance scales (Cuff et al., 2014), Community Balance and Mobility Scale (CB\&M) (Straudi et al., 2017; Sveistrup et al., 2003), and Activities-specific Balance Confidence Scale (ABC) (Thornton et al., 2005). Outcome measures details was described in Table 3.

\subsection{Methodological quality}

PEDro scale was applied to evaluate the risk of bias of the selected studies. Generally, one study was of low methodological quality and received three points (Peters et al., 2014). Three studies (Damiano et al., 2016; Sveistrup et al., 2003; Thornton et al., 2005) were of moderate methodological quality; two studies (Sveistrup et al., 2003; Thornton et al., 2005) received five points while one study (Damiano et al., 2016) received four points. The remaining four were of high quality with a score of eight points (Kleffelgaard et al., 2018), seven points (Cuthbert et al., 2014; Straudi et al., 2017), and six points (Cuff et al., 2014), respectively.

Except for Peters et al. (2014) and Damiano et al. (2016), the included studies had a low risk of bias in the random allocation. Except for Peters et al. (2014), the included studies had a low risk of bias in the group similarity at baseline. All of the included studies have a low risk of bias in the dropouts $<15 \%$. Except for Damiano et al. (2016), the included studies had a low risk of bias in the intention to treat analysis. Except for Cuff et al. (2014), the included studies had a low risk of bias in the point estimate and variability reported. The quality assessment for selected studies ranging from three to eight with six as a median (Table 1).

\subsection{Adverse effects or side effects}

The selected studies did not report any adverse effects, side effects or serious complications in people with TBI following included interventions (Peters et al., 2014; Damiano et al., 2016; Kleffelgaard et al., 2018; Cuthbert et al., 2014; Straudi et al., 2017; Cuff et al., 2014; Sveistrup et al., 2003; Thornton et al., 2005).

\subsection{Effects of VR on balance ability post-TBI}

In the study by Cuthbert et al. (2014), the results of BBS showed that only the experimental VR group had a significant enhancement over time $(0.19$ points per day, $p=0.03)$. However, when comparing differences between groups over the total study period and follow-ups, the VR group had only a 1.13-point higher improvement in BBS scores compared to the control group, which was not significant $(p=0.70)$. Furthermore, the study by Sveistrup et al. (2003) showed that the participants in both the VR and the traditional exercise control group enhanced in the CB\&M after the 6-week intervention period without significant difference. Lastly, in the study by Thornton et al. (2005), although the VR traditional activity balance training control group improved on the ABC scale, the changes were not statistically or clinically significant.

\subsection{Effects of VRT on balance ability post-TBI}

The participants in the VRT experimental group showed significant improvement in BESS scores than the usual multidisciplinary outpatient rehabilitation control group at first follow-up $(2.7 \pm 0.8$ months after baseline assessment $)(P=0.09)$. However, there was no significant difference between groups at the second follow up ( 2 months after the end of intervention), effect size was small to moderate $(0.07-0.39)(P=0.15)$ (Kleffelgaard et al., 2018). Cuff et al. (2014), reported no significant improvement in self-reported balance scale scores in both groups $(p=0.534)$. 
Table 3

Outcome measures

\begin{tabular}{|c|c|c|c|c|c|c|}
\hline $\begin{array}{l}\text { Author, } \\
\text { Year }\end{array}$ & $\begin{array}{l}\text { Outcome } \\
\text { measure }\end{array}$ & $\begin{array}{l}\text { Assessment } \\
\text { time }\end{array}$ & $\begin{array}{l}\text { Experimental group } \\
\text { Mean (SD) }\end{array}$ & $\begin{array}{l}\text { Control group } \\
\text { Mean (SD) }\end{array}$ & $\begin{array}{l}\text { Reported } \\
\text { effect }\end{array}$ & $\begin{array}{l}\text { Effect } \\
\text { size }\end{array}$ \\
\hline \multirow{10}{*}{$\begin{array}{l}\text { Peters et al., } \\
2014\end{array}$} & BBS* & Pre, post 10 & Pre-Test : 50.5 & NA & $=$ & NA \\
\hline & & $\begin{array}{l}\text { sessions (interim), } \\
\text { post } 20 \text { sessions } \\
\text { (post-test), and at a } \\
\text { 3-month follow-up }\end{array}$ & Interim: 50.5 & & & \\
\hline & & & Post-Test: 51 & & & \\
\hline & & & Follow-Up: 49.5 & & & \\
\hline & & & $\begin{array}{l}\text { P: } \text { pre to post }=0.26, \\
\text { pre to } \\
\text { follow-up }=0.24\end{array}$ & & & \\
\hline & DGI* & Pre, after 10 & Pre-Test : 14.5 & NA & $\begin{array}{l}\text { Post interven- } \\
\text { tion:+ }\end{array}$ & NA \\
\hline & & $\begin{array}{l}\text { sessions (interim), } \\
\text { after } 20 \text { sessions } \\
\text { (post-test), and at a } \\
3 \text { month follow-up }\end{array}$ & Interim: 16 & & Follow-up:= & \\
\hline & & & Post-Test: 15.5 & & & \\
\hline & & & Follow-Up: 15 & & & \\
\hline & & & $\begin{array}{l}\mathrm{P} \text { : pre to post }=0.049, \\
\text { pre to } \\
\quad \text { follow-up }=0.9\end{array}$ & & & \\
\hline \multirow[t]{4}{*}{$\begin{array}{l}\text { Damiano } \\
\text { et al., } 2016\end{array}$} & LOS (RT-B) & $\begin{array}{l}\text { Pre and post } \\
\text { intervention }\end{array}$ & Pre: $0.9 \pm 0.3$ & NA & + & NA \\
\hline & & & $\begin{array}{l}\text { Post: } 0.8 \pm 0.2 \\
P=0.03\end{array}$ & & & \\
\hline & $\mathrm{MCT}$ & $\begin{array}{l}\text { Pre and post } \\
\text { intervention }\end{array}$ & Pre: $145.8 \pm 17.2$ & NA & + & NA \\
\hline & & & $\begin{array}{l}\text { Post: } 135.6 \pm 14.4 \\
P=0.001\end{array}$ & & & \\
\hline \multirow[t]{4}{*}{$\begin{array}{l}\text { Kleffelgaard } \\
\text { et al., } 2019\end{array}$} & BESS & $\begin{array}{l}\text { Pre, first follow-up } \\
(2.7 \pm 0.8 \text { months } \\
\text { following baseline } \\
\text { assessment), second } \\
\text { follow-up ( } 2 \\
\text { months after end of } \\
\text { intervention) }\end{array}$ & Pre: $29.7 \pm 11.6$ & Pre: $29.0 \pm 9.6$ & & \\
\hline & & & $\begin{array}{l}\text { First follow-up: } \\
\quad 19.1 \pm 10.6\end{array}$ & $\begin{array}{l}\text { First } \\
\text { follow-up: } \\
23 \pm 9.1\end{array}$ & + & 0.07 \\
\hline & & & $\begin{array}{l}\text { Second follow-up: } \\
17.5 \pm 10.4\end{array}$ & & & 0.39 \\
\hline & & & & $\begin{array}{l}\text { Second } \\
\text { follow-up: } \\
20.8 \pm 9.0\end{array}$ & ++ & 0.34 \\
\hline $\begin{array}{l}\text { Cuthbert et al., } \\
2014\end{array}$ & BBS & $\begin{array}{l}\text { At baseline and at the } \\
\text { end of } 2 \& 4 \mathrm{wks} \text { of } \\
\text { training }\end{array}$ & $\begin{array}{l}\text { Between groups } \\
\quad p=0.70\end{array}$ & & ++ & NA \\
\hline \multirow[t]{8}{*}{$\begin{array}{l}\text { Straudi et al., } \\
2017\end{array}$} & UBS* & $\begin{array}{l}\text { Pre and post } \\
\text { intervention }\end{array}$ & Pre: 43 & Pre:49 & + & NA \\
\hline & & & Post: 49.5 & Post:51 & & \\
\hline & $\mathrm{CB} \& \mathrm{M}$ & $\begin{array}{l}\text { Pre and post } \\
\text { intervention }\end{array}$ & Pre: 17 & Pre: 25 & ++ & NA \\
\hline & & & Post: 25 & Post: 25.5 & & \\
\hline & $\begin{array}{l}\text { ML path length } \\
(\mathrm{mm})^{*}\end{array}$ & & Pre: 154.9 & Pre: 169.5 & $=$ & NA \\
\hline & & & Post: 140.7 & Post: 201.0 & & \\
\hline & $\begin{array}{l}\text { AP path length } \\
(\mathrm{mm})^{*}\end{array}$ & & Pre: 223.7 & Pre: 258.3 & $=$ & NA \\
\hline & & & Post: 171.2 & Post: 262.7 & & \\
\hline
\end{tabular}


Table 3

(continued)

\begin{tabular}{|c|c|c|c|c|c|c|}
\hline $\begin{array}{l}\text { Author, } \\
\text { Year }\end{array}$ & $\begin{array}{l}\text { Outcome } \\
\text { measure }\end{array}$ & $\begin{array}{l}\text { Assessment } \\
\text { time }\end{array}$ & $\begin{array}{l}\text { Experimental group } \\
\text { Mean (SD) }\end{array}$ & $\begin{array}{l}\text { Control group } \\
\text { Mean (SD) }\end{array}$ & $\begin{array}{l}\text { Reported } \\
\text { effect }\end{array}$ & Effect size \\
\hline & $\begin{array}{c}\text { Sway speed } \\
(\mathrm{mm} / \mathrm{s})^{*}\end{array}$ & & Pre: 15.6 & Pre: 18.2 & $=$ & NA \\
\hline & & & Post: 12.7 & Post: 20.9 & & \\
\hline & $\begin{array}{l}\text { Tot path length } \\
(\mathrm{mm})^{*}\end{array}$ & & Pre: 309.5 & Pre: 362.0 & $=$ & NA \\
\hline & & & Post: 252.1 & Post: 416.3 & & \\
\hline $\begin{array}{l}\text { Cuff et al., } \\
2014\end{array}$ & $\begin{array}{l}\text { Self-reported } \\
\text { balance scale }\end{array}$ & $\begin{array}{l}\text { Pre and post } \\
\text { intervention }\end{array}$ & $\begin{array}{l}\text { Between groups } \\
\quad p=0.534\end{array}$ & - & $=$ & NA \\
\hline \multirow[t]{2}{*}{$\begin{array}{l}\text { Sveistrup } \\
\text { et al., } 2003\end{array}$} & $\mathrm{CB} \& \mathrm{M}$ & $\begin{array}{l}\text { Pre, post intervention, } \\
\text { and 6-month } \\
\text { follow-up }\end{array}$ & Post: $P \geq 0.05$ & - & $=$ & NA \\
\hline & & & Follow-up & Post: $P \geq 0.05$ & ++ & \\
\hline \multirow[t]{3}{*}{$\begin{array}{l}\text { Thornton } \\
\text { et al., } 2005\end{array}$} & $\mathrm{ABC}$ & $\begin{array}{l}\text { Pre, post-intervention } \\
\text { and 3-month } \\
\text { follow-up }\end{array}$ & Pre: 74.8 & Pre: $74 . \overline{6}$ & ++ & NA \\
\hline & & & Post: 80.2 & Post: 76.4 & & \\
\hline & & & Follow-up: 81.2 & $\begin{array}{l}\text { Follow-up: } \\
78.2\end{array}$ & & \\
\hline
\end{tabular}

BBS: Berg Balance Scale; LOS (RT-B): limits of stability- reaction time backwards; MCT: motor control test; BESS, Balance Error Scoring System; UBS: Unified Balance Scale; ML: mediolateral; AP: anteroposterior; CB\&M: Community Balance and Mobility Scale; ABC: Activities-specific Balance Confidence Scale. *, Presented as a Median; +, significant improvement in experimental group only; =, no significant differences between experimental and control group; ++, both groups improved without significant difference.

\subsection{Effects of other physiotherapy interventions on balance ability post-TBI}

In the study by Straudi et al. (2017), both the experimental video game therapy group and balance platform therapy control group improved significantly in CB\&M scores with no significant difference between groups. The experimental group improved significantly in UBS scores than the control group. Moreover, Damiano et al. (2016) reported improvement in both LOS (RT-B) and MCT scales scores in the experimental group (patients with TBI), no between-group differences values were reported after elliptical training. Lastly, the pilot study by Peters et al. (2014), reported improvement in BBS scores. The patients demonstrated significant improvement in DGI scores at the end of the mobility training, however, no significant improvement was reported at the 3-month follow-up (Peters et al., 2014).

\section{Discussion}

This is the first review that examined the effects of physical therapy interventions on balance ability post-TBI. The preliminary results show no superior effects of VR, VRT, video game therapy, elliptical training, and mobility training on balance ability in patients with TBI compared to other traditional rehabilitation interventions. This is similar to Murray (2016), who demonstrated in his systematic review that the evidence for the effectiveness of VRT post mild TBI (mTBI)/concussion is limited. Booth et al. (2018) reported in their systematic review that there was a moderate to strong impact of VRT on decreasing of dizziness and balance impairments in participants with concussions, however, the systematic review included two randomized controlled trials and four case series studies, and thus the confirmed conclusion cannot be drawn. Besides, the evidence about the using of VR in the rehabilitation of TBI in improving motor and cognitive functionality is currently very limited (Pietrzak et al., 2014). VR offers augmented feedback during training that can afford to learn motor skills (Lauber \& Keller, 2012). VR also increases individuals' attention and motivation, which are crucial components of learning (Wulf, 2013). Furthermore, the traditional rehabilitation interventions can improve the balance and body stability based on motor learning principles particularly tailored for treating postural deficits in an open trial done on patients with mild-to-moderate TBI (Pietrzak et al., 2014).

Except for Peters et al. (2014) and Damiano et al. (2016), the selected studies were randomized controlled trials. Two of the selected studies failed to random allocation (Peters et al., 2014; Damiano et al., 2016). Except for Kleffelgaard et al. (2019), the 
selected studies failed to concealed allocation. One study failed the groups to be similar at baseline (Peters et al., 2014). All selected studies had poor results in the participants and therapist blinding leading to potential bias. Four studies did not blind the assessor (Peters et al., 2014; Damiano et al., 2016; Sveistrup et al., 2003; Thornton et al., 2005). One study did not intend to treat analysis (Damiano et al., 2016). Four studies did not report Between-group differences (Peters et al., 2014; Damiano et al., 2016; Sveistrup et al., 2003; Thornton et al., 2005). Finally, one study failed to report point estimate and variability (Cuff et al., 2014).

Three studies used VR training to improve balance in individuals with TBI (Cuthbert et al., 2014; Sveistrup et al., 2003; Thornton et al., 2005). One study (Cuthbert et al., 2014) was of high quality on the PEDro scale, however, the sample size was small $(<25)$. Due to the small sample size, meaningful differences cannot be established (Portney \& Watkins, 2009). Hence, poor statistical power is probable which led to inadequate evidence, so it is not probable to confirm the clinical importance of the reported effects. The remaining two were of moderate quality (Sveistrup et al., 2003; Thornton et al., 2005), and had a large sample size. However, no significant difference was found between groups. So the clinical sense of described effects cannot be recognized. Concerning vestibular rehabilitation therapy, two studies used VRT to improve balance in individuals with TBI (Kleffelgaard et al., 2018; Cuff et al., 2014). Both studies were of high quality, which they are a randomized controlled trial with a large sample size. They were high to moderate on the PEDro scale. However, no significant difference was found between groups. So it is not likely to create the experimental importance of the stated effects. Moreover, in the study by Straudi et al. (2017), video game therapy was used to improve the balance in individuals with TBI. This study was of high quality on the PEDro scale with small sample size. As a small sample size, a significant difference cannot be calculated. Furthermore, Peters et al. (2014), mobility training were used to improve the balance in individuals with TBI. This study was of low quality on the PEDro scale and the sample size was small. So the clinical meaning of reported effects cannot be established. Finally, in the study by Damiano et al. (2016), the rapid-resisted elliptical training program was used to improve the balance in individuals with TBI. This study was of low quality on the PEDro scale and the sample size was small. So it is not possi- ble to confirm the clinical importance of the reported effects.

Balance deficit is one of the most serious impairments to treat in patients with TBI due in part to numerous structures involved in preserving balance and in part to the insufficiency of current treatment techniques (Mann et al., 1996). Maintaining balance while sitting and standing are necessary for all daily activities, including self-care, walking, and driving (Peterson \& Greenwald, 2015). The common causes of balance deficits after traumatic brain injury include medications, postural hypotension, vision impairments, vestibular impairments, sensory impairments, brainstem injury, perilymph fistula, and mental health issues (i.e: anxiety, depression, or a fear of falling). In this context, balance problems can occur due to different causes, each one requiring a different treatment.

It has been shown that when healthy individuals stand on a stable surface with obtainable visual input, sensory contributions compromised of $70 \%$ somatosensory inputs, 20\% vestibular inputs, and $10 \%$ visual inputs (Peterka, 2002). When somatosensory efficacy was decreased through support surface oscillations, sensory recalibration altered the contributions to $70 \%$ vestibular inputs, $20 \%$ visual inputs, and $10 \%$ somatosensory inputs to keep the stability (Peterka, 2002). Based on this findings, the somatosensory and vestibular systems appear to be the main sensory systems to obtain postural control during standing (Peterka, 2002). In this context, we propose that stimulate visual, vestibular, and/or somatosensory at the same time such as; vestibular exercises while standing on WBV, VR on WBV or VR on treadmill may alter the neuroplasticity on multiple levels of the nervous system, which could provide maximum benefit in improving balance ability in those with TBI and other populations.

The current review has some limitations. There is language bias in the searching process; the search was restricted by articles published in the English language. Informal studies were not selected. This can lead to selective bias as research papers with significant findings are more likely to get accepted than papers that fail to demonstrate significant findings (Egger \& Smith, 1998). Studies with significant findings are gernerally published in English language (Egger \& Smith, 1998). Consequently, reviewing only articles published in English language could lead to an overestimation of therapy influences (Higgins \& Altman, 2008). The effect size was not calculated in most studies because there is insufficient and 
inadequate data. Meta-analysis was not performed due to heterogeneity.

The relationship between duration, severity of TBI and the dose of the physical therapy intervention remain unclear. Also, while there is no sufficient evidence to support the superior effect of included physical therapy interventions such as; VR, VRT and video game therapy on balance ability in individuals with TBI. Besides, there was evidence for a positive effect of other physical therapy interventions such as; WBV (Alashram et al., 2019), MT (Xu et al., 2018), and TCE (Ustinova et al., 2015) on balance ability in individuals with other neurological disorders. We propose that using these interventions with individual's post-TBI may show beneficial effects. High-quality randomized controlled trials including large sample sizes are needed.

\section{Conclusion}

There is paucity in studies that investigate the effects of physical therapy interventions on balance impairments post-TBI. To date, the preliminary findings showed that the impact of physical therapy on the balance ability in individuals with TBI was limited. The selection of physical therapy intervention should depend on the cause of balance deficits. We propose that stimulation of multi-systems at the same time may alert the neuroplasticity in patients with balance impairments. Additional randomized controlled trials with a large sample size are strongly needed to clarify the role of physical therapy in an individual's post-TBI with balance deficits and to verify our hypothesis.

\section{Conflict of interest}

The authors have no source of funding or any potential conflicts of interest to disclose.

\section{References}

Alashram, A., Annino, G., \& Mercuri, N. (2019a). Rhythmic auditory stimulation in gait rehabilitation for traumatic brain and spinal cord injury. Journal of Clinical Neuroscience, 69, 287288.

Alashram, A., Padua, E., \& Annino, G. (2019b). Effects of Whole-Body Vibration on Motor Impairments in Patients with Neurological Disorders. American Journal of Physical Medicine \& Rehabilitation, 98(12), 1084-1098.
Alashram, A., Padua, E., Hammash, A., Lombardo, M., \& Annino, G. (2020). Effectiveness of virtual reality on balance ability in individuals with incomplete spinal cord injury: A systematic review. Journal of Clinical Neuroscience.

Booth, M., Powell, J., McKeon, P., \& Medina McKeon, J. (2019). Vestibular Rehabilitation Therapy for Management of Concussion: A Critically Appraised Topic. International Journal of Athletic Therapy And Training, 24(3), 100-107.

Broderick, P., Horgan, F., Blake, C., Ehrensberger, M., Simpson, D., \& Monaghan, K. (2018). Mirror therapy for improving lower limb motor function and mobility after stroke: A systematic review and meta-analysis. Gait \& Posture, 63, 208-220.

Chen, B., Guo, J., Liu, M., Li, X., Zou, J., \& Chen, X. et al. (2015). Effect of Traditional Chinese Exercise on Gait and Balance for Stroke: A Systematic Review and Meta-Analysis. PLOS ONE, 10(8), e0135932.

Cohen, J. (1988). Statistical power analysis for the behavioural sciences. Hillside, NJ, Lawrence 519: Earlbaum Associates.

Cuff, S., Rose, S., \& Young, J. (2014). Early intervention in pediatric concussion patients with dizziness and balance problems. Clin J Sport Med, 24, 186-187.

Cuthbert, J., Staniszewski, K., Hays, K., Gerber, D., Natale, A., \& O'Dell, D. (2014). Virtual reality-based therapy for the treatment of balance deficits in patients receiving inpatient rehabilitation for traumatic brain injury. Brain Injury, 28(2), 181-188.

Damiano, D., Zampieri, C., Ge, J., Acevedo, A., \& Dsurney, J. (2016). Effects of a rapid-resisted elliptical training program on motor, cognitive and neurobehavioral functioning in adults with chronic traumatic brain injury. Experimental Brain Research, 234(8), 2245-2252.

Egger, M., \& Smith, G. (1998). Meta-analysis bias in location and selection of studies. BMJ, 316(7124), 61-66.

Feld, J., Rabadi, M., Blau, A., \& Jordan, B. (2001). Berg Balance Scale and Outcome Measures in Acquired Brain Injury. Neurorehabilitation and Neural Repair, 15(3), 239-244.

Greenwald, B., Cifu, D., Marwitz, J., Enders, L., Brown, A., Englander, J., \& Zafonte, R. (2001). Factors Associated with Balance Deficits on Admission to Rehabilitation after Traumatic Brain Injury: A Multicenter Analysis. Journal of Head Trauma Rehabilitation, 16(3), 238-252.

Higgins, J., \& Altman, D. (2008). Cochrane Handbook for Systematic Reviews of Interventions. Hoboken: Wiley.

Hsieh, C., Sheu, C., Hsueh, I., \& Wang, C. (2002). Trunk Control as an Early Predictor of Comprehensive Activities of Daily Living Function in Stroke Patients. Stroke, 33(11), 2626-2630.

Ialongo, C. (2016). Understanding the effect size and its measures. Biochemia Medica, 26(2), 150-163.

Kertia Black, Ross Zafonte, \& Scott M. (2000). Sitting balance following brain injury: does it predict outcome? Brain Injury, 14(2), 141-152.

Kleffelgaard, I., Soberg, H., Tamber, A., Bruusgaard, K., Pripp, A., Sandhaug, M., \& Langhammer, B. (2018). The effects of vestibular rehabilitation on dizziness and balance problems in patients after traumatic brain injury: a randomized controlled trial. Clinical Rehabilitation, 33(1), 74-84.

Lauber, B., \& Keller, M. (2012). Improving motor performance: Selected aspects of augmented feedback in exercise and health. European Journal of Sport Science, 14(1), 36-43.

Liberati, A., Altman, D., Tetzlaff, J., Mulrow, C., Gøtzsche, P., \& Ioannidis, J. et al. (2009). The PRISMA Statement for 
Reporting Systematic Reviews and Meta-Analyses of Studies That Evaluate Health Care Interventions: Explanation and Elaboration. Plos Medicine, 6(7), e1000100.

Maher, C., Sherrington, C., Herbert, R., Moseley, A., \& Elkins, M. (2003). Reliability of the PEDro Scale for Rating Quality of Randomized Controlled Trials. Physical Therapy, 83(8), 713721.

Mann, G., Whitney, S., Redfern, M., Borello-France, D., \& Furman, J. (1996). Functional Reach and Single Leg Stance in Patients with Peripheral Vestibular Disorders. Journal of Vestibular Research, 6, 343-353.

Marsh, N., Ludbrook, M., \& Gaffaney, L. (2016). Cognitive functioning following traumatic brain injury: A five-year follow-up. Neurorehabilitation, 38(1), 71-78.

Murray, D., Meldrum, D., \& Lennon, O. (2016). Can vestibular rehabilitation exercises help patients with concussion? A systematic review of efficacy, prescription and progression patterns. British Journal of Sports Medicine, 51(5), 442-451.

Peterka, R. (2002). Sensorimotor Integration in Human Postural Control. Journal of Neurophysiology, 88(3), 1097-1118.

Peters, D., Jain, S., Liuzzo, D., Middleton, A., Greene, J., \& Blanck, E. et al. (2014). Individuals With Chronic Traumatic Brain Injury Improve Walking Speed and Mobility With Intensive Mobility Training. Archives of Physical Medicine and Rehabilitation, 95(8), 1454-1460.

Peterson, M., \& Greenwald, B. (2015). Balance Problems After Traumatic Brain Injury. Archives of Physical Medicine and Rehabilitation, 96(2), 379-380.

Pietrzak, E., Pullman, S., \& McGuire, A. (2014). Using Virtual Reality and Videogames for Traumatic Brain Injury Rehabilitation: A Structured Literature Review. Games for Health Journal, 3(4), 202-214.

Portney, L., \& Watkins, M. (2009). Foundations of clinical research (3rd ed.). Prentice Hall: Upper Saddle River.

Sackett, D. (1989). Rules of evidence and clinical recommendations on the use of antithrombotic agents. Chest, 95(2), 2S-4.

Schmid, A., Van Puymbroeck, M., Altenburger, P., Schalk, N., Dierks, T., \& Miller, K. et al. (2012). Poststroke Balance Improves With Yoga. Stroke, 43(9), 2402-2407.
Shaffer, S., \& Harrison, A. (2007). Aging of the Somatosensory System: A Translational Perspective. Physical Therapy, 87(2), 193-207.

Shumway-Cook, A., Anson, D., \& Haller, S. (1988). Postural sway biofeedback: its effect on reestablishing stance stability in hemiplegic patients. Arch Phys Med Rehabil, 69(6), 395-400.

Straudi, S., Severini, G., Sabbagh Charabati, A., Pavarelli, C., Gamberini, G., Scotti, A., \& Basaglia, N. (2017). The effects of video game therapy on balance and attention in chronic ambulatory traumatic brain injury: an exploratory study. $B M C$ Neurology, 17(1).

Sveistrup, H., McComas, J., Thornton, M., Marshall, S., Finestone, H., \& McCormick, A. et al. (2003). Experimental Studies of Virtual Reality-Delivered Compared to Conventional Exercise Programs for Rehabilitation. Cyberpsychology \& Behavior, 6(3), 245-249.

Thornton, M., Marshall, S., McComas, J., Finestone, H., McCormick, A., \& Sveistrup, H. (2005). Benefits of activity and virtual reality based balance exercise programmes for adults with traumatic brain injury: Perceptions of participants and their caregivers. Brain Injury, 19(12), 989-1000.

Ustinova, K., Chernikova, L., Dull, A., \& Perkins, J. (2014). Physical therapy for correcting postural and coordination deficits in patients with mild-to-moderate traumatic brain injury. Physiotherapy Theory and Practice, 31(1), 1-7.

Wade, L., Canning, C., Fowler, V., Felmingham, K., \& Baguley, I. (1997). Changes in postural sway and performance of functional tasks during rehabilitation after traumatic brain injury. Archives of Physical Medicine and Rehabilitation, 78(10), 1107-1111.

Walker, W., \& Pickett, T. (2007). Motor impairment after severe traumatic brain injury: A longitudinal multicenter study. The Journal of Rehabilitation Research and Development, 44(7), 975-982.

Wulf, G. (2013). Attentional focus and motor learning: a review of 15 years. International Review of Sport and Exercise Psychology, 6(1), 77-104.

Xu, L., Dong, Y., Wang, M., Chen, L., Zhang, Z., \& Su, D. et al. (2018). Acupuncture for balance dysfunction in patients with stroke. Medicine, 97(31), e11681. 